\title{
Persistent Classroom Management Training Needs of Experienced Teachers
}

\section{Laura M. Stough, ${ }^{1}$ Marcia L. Montague, ${ }^{2}$ Leena Jo Landmark, ${ }^{3}$ and Kendra Williams-Diehm ${ }^{4}$}

\begin{abstract}
Experienced special education teachers $(n=62)$ were surveyed on their professional preparation to become effective classroom managers. Despite having received extensive preservice training, over $83 \%$ of the sample reported being underprepared in classroom management and behavioral interventions. No statistically significant difference was found with respect to the type of classroom management theoretical approach used to train these teachers. Of those (74.2\%) who received classroom management training post-graduation, the majority (64\%) reported needing still further training in dealing with student behavior. Specific training desired was in whole-class management strategies, as well as in managing behaviors of students with disabilities. Results suggest that teachers' training needs in classroom management may persist throughout their professional careers, even following intensive preservice training.
\end{abstract}

Key Words: classroom management, teacher preparation, teacher training, special education

A number of researchers assert that pedagogical knowledge is a critical component of teacher effectiveness (e.g. Darling-Hammond, 2000; Berry, Hoke, \& Hirsch, 2004; Emmer \& Stough, 2001; Kaplan \& Owings, 2003; Oliver \& Reschly, 2007). This argument is particularly evidenced in studies on classroom management. Positive student achievement gains are regularly found when instruction is accompanied by effective classroom management (e.g. Omoteso \& Semudara, 2011; Stronge, Ward, \& Grant, 2011). In some studies, effective classroom management has been found to impact student achievement even more than factors such as intelligence scores and socioeconomic status (Anderson, Evertson, \& Brophy, 1979; Gettinger \& Kohler, 2006; Wang, Haertel, \& Walberg, 1993). However, classroom management is rarely taught as a stand-alone course within university teacher education programs; rather, it is content that is usually inserted into other pedagogical coursework (Brophy, 2006; Oliver \& Reschly, 2010; Stough, 2006). Such practice within training programs is puzzling in light of persistent reports that preparedness in classroom management is a priority for teachers.

Novice teachers consistently identify classroom management as a primary concern (Brophy, 2006; Nahal, 2010; Watson, 2006). These findings have persisted for over 50 years. Veenman (1984) reported that beginning teachers identified discipline as their most frequently perceived concern in $77 \%$ of 91 studies reviewed as part of a meta-analysis. Meister and Melnick (2003) found a nationwide sample of 273 beginning teachers reported managing behaviors as a primary concern, with only $67 \%$ believing they could manage the behavioral problems of students

\footnotetext{
${ }^{1}$ Department of Educational Psychology, Texas A\&M University, TAMU 4225, College Station, TX 77843

2 Department of Educational Psychology, Texas A\&M University, TAMU 4225, College Station, TX 77843

${ }^{3}$ Department of Teacher Education, Ohio University, 1 Ohio University, Athens, OH 45701

${ }^{4}$ Department of Educational Psychology, University of Oklahoma, 820 Van Vleet Oval, Norman, OK 73019
} 
with disabilities. Most recently, a study of 1,690 first year teachers with limited training in pedagogy reported themselves ill-prepared to handle classroom management or discipline (Kee, 2011).

Novice special education teachers similarly report that university training does not adequately prepare them for their teaching assignments. In a study of 147 new special education teachers from seven different states in the U.S., 60\% reported needing assistance with behavior management during their first year of teaching. Further, $83 \%$ of beginning special education teachers who needed assistance asked for mentoring related to classroom behavior management (White \& Mason, 2006). Likewise, Whitaker (2003) surveyed 156 beginning special education teachers and found classroom management to be one of eight areas in which new teachers wanted additional assistance.

Even experienced teachers report low self-efficacy (Baker, 2005) or a lack of preparedness (Watson, 2006) in the area of classroom management. A sample of 752 experienced educators ranked classroom management, instructional planning, and behavior management as the three most important instructional competencies needed in inclusive settings (MacPherson-Court, McDonald, \& Sobsey, 2003). In addition, the majority of these experienced teachers believed that general and special education teachers needed preservice training in behavior management techniques as well as in classroom management (MacPherson-Court et al., 2003). Finally, 64\% of a combined sample of 228 novice and experienced special education teachers reported having received insufficient university preparation in behavior management (Mitchell \& Arnold, 2004).

\section{Classroom Management and Teacher Preparation}

Given the importance of classroom management to teachers, it seems that classroom management training would be a key component of all teacher preparation programs. However, teacher preparation programs differ in the extent to which classroom management is provided. Oliver and Reschly (2010) found only $27 \%$ of 26 reviewed special education teacher training programs included a stand-alone course in classroom management. In addition, programs differ in how classroom management is taught (Gilberts \& Lignugaris-Kraft, 1997; Stough \& Montague, 2015). For example, preservice teachers typically take the same coursework early in their university careers. However, as they progress through their programs, the training paths of general educators and special educators begin to diverge (Stough \& Montague, 2015; Stough, Williams-Diehm, \& Montague, 2004). General education preservice training typically focuses on content and group instruction, while training for special education preservice teachers tends to focus on modifications of the general education curriculum and individual instruction (Brownell, Ross, Colon, \& McCallem, 2005). As a result, classroom management taught as part of a special education program tends to emphasize individual approaches to behavioral problems, rather than whole class management (Oliver \& Reschly, 2010). Conversely, when classroom management is taught as part of a general education program, the pedagogical emphasis is on management and procedures for the whole class (Stough et al., 2004). Examinations of teacher preparation programs also suggest that teachers who complete traditional four-year university preparation programs tend to be more skilled in classroom management than are their peers who complete briefer programs such as Teach for America or other alternative certification programs (Brophy, 2006; Darling-Hammond, 2000; Schoenfeld \& Feinman, 2012).

However, research on classroom management content delivered in university training programs is limited. In one of the only studies on models of behavior and classroom management 
used in teacher education programs, O'Neill and Stephenson (2012) studied graduates from 21 different Australian teacher preparation programs. While teachers reported being familiar with an average of 12 classroom management models introduced during their preservice programs, the number of models they felt confident in using was much lower- an average of 3. However, O'Neill and Stephenson (2012) found that an increase in classroom management content also increased the number of strategies teachers were confident in using in the classroom. Increase in classroom management content also made teachers feel more prepared to deal with student misbehaviors. However, while the components of quality classroom management training have been described in the literature (e.g. Jones, 2006; Stough \& Montague, 2015), no research has been done on how differences in content affect teachers' skills in classroom management.

\section{Classroom Management Models}

Glickman and Tamashiro (1980) have described three overarching schools of thought regarding approaches to whole classroom management; interventionist, interactionalist, or noninterventionist. For example, Jones' (1987) Classroom Discipline can be classified as an interventionist model in that it is neo-Skinnerian and assumes that children need to be externally controlled in order to learn to behave appropriately, while Gordon's Teacher Effectiveness Training (1974), can be classified as a non-interventionist approach to classroom management as it assumes that students are self-regulating and thus can learn to manage their own behavior. Gathercoal's (1990) Judicious Discipline is an example of an interactionalist approach in that it focuses both on how teachers create behavior systems in the classroom and how to involve students in creating classroom rules and regulating their personal behavior. Martin, Shoho, \& Yin (2003) have found that inexperienced teachers are more likely to take an interventionist approach to classroom management than are their more experienced counterparts. In contrast, experienced special education teachers are more likely to reflect on students' typical patterns of behavior than are novice special education teachers (Stough \& Palmer, 2001), which suggests that more experienced teachers tend towards an interactionalist approach.

Few studies have examined the quality of teacher preparation programs in special education (Brownell, et. al, 2005) and little research has been done on the classroom management practices of special educators (Brophy, 2006). The purpose of our study was to investigate the extent to which classroom management training prepares special education teachers to address classroom management. We were also interested in how different preservice classroom management approaches might affect teacher satisfaction with their training. We wished to answer the following research questions:

1. To what extent was university teacher preparation in classroom management helpful?

2. What type of classroom management coursework was the most helpful?

3. In which settings did the teachers learn the most about classroom management?

4. What type of training in classroom management was received post-certification?

5. Do experienced special education teachers want more training in classroom management?

\section{Method}

In this study, experienced teachers who had graduated from a university training program in special education were asked about the extent to which their training had adequately prepared them for classroom management. Training included 19 courses specific to pedagogy, as well as 6 fieldwork-

Journal of the Scholarship of Teaching and Learning, Vol. 15, No. 5, October, 2015. 
intensive courses, representing five semesters of college study. One pedagogy course specifically focused on classroom and behavior management. Training included most of the recommended components recommended by Jones (2006), including classroom management knowledge, low faculty-student ratio, the opportunity to reflect and discuss management issues, a careful process for selecting mentors, and instruction from experienced teachers.

Over the 12 years of the program, six different instructors had taught the required course in classroom management and behavior. In order to categorize the approach presented in the course over this time period, the syllabi of each of these instructors was obtained and analyzed. We examined the different theoretical and training components that were used to deliver classroom management content in these courses. In some cases, the instructors were contacted to clarify the type of content and fieldwork that had been included as part of their course so that we could gain a better understanding of the components of the course. We found that instructors used one of two distinctly different approaches to management. In the first, an interventionist approach was used wherein Neo-Skinnerian theory was the predominate theoretical approach used and the focus was on individual student behavior. In these courses, interventions were individualized and consequences for responding to student behavior was emphasized. In the second approach, instructors used an interactionalist whole-class approach, wherein classroom management theories that addressed group student and instructional management were emphasized. In this whole-class approach, eight different models of classroom management were introduced, however the focus was always on using each of these approaches as part of the management of the whole classroom. In addition, we analyzed if each course contained field based experiences and the extent to which these experiences were integrated with classroom instruction. As a result, we were able to categorize each course as having either a distinct focus on individual interventionist or on wholeclass interactionalist management strategies, as well as whether or not each class included a fieldbased component.

Although there were differences in the approaches used by the instructors, there were considerable similarities in how these courses were structured. All courses had the same course description and were taught by members of the same faculty. Courses were taught during a full 15 -week semester as part of a required curriculum in special education. Classroom and behavior management competencies required as part of special education National Council for Accreditation of Teacher Education (NCATE) standards were included in each class. Class sizes were no larger than 35 students, consisted of more than $90 \%$ female students, and were taken in cohort during the junior or senior year of the program. Instructors all had at least three years of experience as special education teachers themselves and were either doctoral candidates or held $\mathrm{PhDs}$ from nationally recognized colleges of education.

\section{Participants}

Participants were graduates of a university training program which produced one of the largest number of special educators in the southwestern U.S. All of the participants had graduated before 2004; therefore, the recruitment pool consisted entirely of experienced teachers. A database of 364 graduates was used to locate participants. Searches were complicated as the sample was relatively young and mobile, as well as overwhelmingly female, many with changes in surnames. Researchers used multiple sources, including university records, state teacher certification records, internet searches, and telephone directories to locate accurate telephone numbers for those in the database. When the current school district in which a graduate was employed could be identified,

Journal of the Scholarship of Teaching and Learning, Vol. 15, No. 5, October, 2015. 
the internet, telephone, or email was used to attempt to contact the participant at that district location. Verifiable telephone numbers for 208 graduates were obtained. Researchers attempted to contact each of the 208 graduates a minimum of three times over a period of two months. A total of 62 completed surveys were obtained for a response rate of $29.8 \%$.

Of the participants, $60(96.8 \%)$ were female with a mean age of 28 years old. Thirty-four $(54.8 \%)$ participants were currently employed as teachers and the majority (59\%) had taught for 3 years or more, with an average teaching experience at the time of the survey of 3.6 years. Of those currently teaching, 27 (65.9\%) were teaching in a mid-size district, $9(22.0 \%)$ were teaching in a rural district, and $5(12.2 \%)$ were teaching in an urban district. Although there was a slight tendency for more recent graduates to respond to the survey, there were not any significant differences in sex, age, or ethnicity of the participants versus the non-participants.

Employment positions for respondents at the time of the survey included $29(46.7 \%)$ special education teachers, $3(4.8 \%)$ general education teachers, 8 (12.9\%) non-teaching school employees (e.g., diagnosticians, administrators), 5 (8.1\%) other education-related employees (e.g., private behavior therapists), 7 (11.3\%) non education-related employees, and 10 (16.1\%) homemakers. Of those respondents who were no longer teaching in the field of special education, factors which influenced their decision to leave included personal reasons (17), career changes within the field of education (8), career changes out of education (4), and negative experiences in previous educational positions (4).

\section{Survey Development}

A structured telephone survey was used to collect data for this study. Three of the authors discussed and drafted survey questions for special education teachers. The survey was then piloted on nine teachers who had completed university certified special education programs. The final survey consisted of a total of 18 items including 1 multiple choice, 6 short-answer, 2 Likert scale items, as well as 9 questions pertaining to teacher demographics, preservice training, and inservice training in classroom management. All survey respondents were asked the same set of questions by one of two researchers. A written telephone script containing all the elements of consent, as well as a brief description of the study, was read to all participants. Responses were marked simultaneously on a coding form as the participants answered the survey questions.

\section{Data Analysis}

Quantitative data from each survey were coded and entered into the database by one member of the research team while a second researcher checked entries for accuracy. In a few cases, respondents were contacted an additional time to clarify their responses. To code the responses to the open-ended questionnaire items, two of the researchers independently reviewed all responses and then generated an initial list of categories for each variable. A third researcher then created a final list of categories for each variable. The four open-ended survey questions were then coded by the first two researchers. Interrater reliability was calculated to verify category coding; the interrater reliability of coding each category ranged between 80 to $96 \%$. After interrater reliability was determined, two of the researchers examined the incidences of difference jointly and determined which code should be used for further analysis. Descriptive statistics were calculated on the demographic characteristics and t-tests were conducted between several of the quantitative survey items. 
Stough, Montague, Landmark, and Williams-Diehm

\section{Results}

To what extent was university teacher preparation helpful?

Participants were asked to reflect on the classroom management course they had taken as part of their undergraduate program and to respond to a series of questions specifically related to that course. Using a 5-point Likert-scale that ranged from "not at all" to "extremely well," participants were asked, "To what extent did this management course adequately prepare you for the classroom?" Fifty-two percent (31) of the participants reported that their classroom management course, regardless of theoretical approach, had prepared them well or extremely well for classroom teaching. Thirty-five percent (22) of the participants reported that they had been prepared "somewhat." Six participants reported that the course had not prepared them very little or not at all. Three respondents could not recall any details about the course that they had taken.

However, the majority $(83.9 \%)$ of the sample responded that they would have liked even more training in classroom management during their university teacher training program. In response to an open-ended question about what type of additional training was desired, four different categories were generated: general classroom management techniques (24), management-related fieldwork (17), disability-specific strategies (13), and case studies/role playing scenarios (5).

\section{What type of theoretical approach to classroom management was the most helpful?}

We examined if coursework received by these teachers had employed either (a) an individual interventionist approach to classroom management, wherein the instructional focus was on changing individual student behaviors, or (b) an interactionalist classroom management approach to instruction, wherein the instructional focus was on how to most effectively manage the class as a whole. Graduates who had received coursework based on an individual interventionist approach were compared with graduates who had received an interactionalist whole-class approach. No statistically significant difference was found regarding preparedness for teaching between the teachers who were taught with an individual-interventionist approach and teachers who were taught with an interactionalist classroom management approach $(t(57)=.042, p>.05, d=.012)$.

In addition, we analyzed the relative effectiveness of those courses that included fieldbased experiences. Respondents who had taken field-based courses, did not rate these courses more highly with respect to their effectiveness than did participants enrolled in non-field-based programs $(t(57)=.677 p>.05, d=.179)$. In addition, no statistically significant differences were found between these two types of courses with respect to perceptions of how well they prepared the respondents for teaching $(t(57)=-.118, p>.05, d=.036)$.

In which settings did the teachers learn the most about classroom management?

Respondents responded to an open-ended question, "Where did you learn the most about classroom management or behavioral intervention?" Four different categories of responses were coded. Thirty-eight $(61.3 \%)$ of the respondents reported that they had learned the most about classroom management and behavioral intervention through teaching students in their own classrooms. Sixteen $(25.8 \%)$ of the respondents indicated that they learned the most from 
Stough, Montague, Landmark, and Williams-Diehm

fieldwork completed before they had graduated, while $15(24.2 \%)$ of the respondents indicated that they learned the most as part of their university coursework. Two respondents $(3.2 \%)$ reported that they had learned the most through substitute teaching experiences.

\section{What type of training in classroom management was received post-certification?}

Respondents were asked if they had received additional training in classroom management after graduation. A majority of the respondents (74.2\%) had received additional professional development. Those who answered affirmatively were asked to identify the type of training they had received. Training was received primarily in one of three forms; as part of in-service or workshop education $(87.0 \%)$, a university course $(21.7 \%)$, or through a behavioral consultant (6.5\%). Specific types of professional development training identified included Boys Town, Nonviolent Crisis Intervention, Applied Behavior Analysis (ABA), Capturing Kids' Hearts, Consistency Management \& Cooperative Discipline, Building Better Boys, and Love and Logic.

Do experienced special education teachers want more training in classroom management?

Sixty-four percent of the respondents (40) expressed the desire for continued professional development in the area of classroom management or behavioral intervention. When asked specifically what type of additional training they needed, three different categories of training were mentioned: $40 \%$ (16) of these teachers referenced interactionalist whole-classroom management strategies as important, while 25\% (10) desired training in managing behaviors associated with particular disabilities (e.g. autism, Down Syndrome, emotional disturbance). Twenty-five percent (10) described other management or behavior-related training.

All $62(100 \%)$ of the respondents believed that a course focusing on management pedagogy should be required for both general and special education teachers. Using a 5-point Likert-scale that ranged from "not at all" to "extremely well," participants were asked, "Is it important to offer a separate course in classroom management or behavioral intervention?" A majority (91.9\%) of the respondents felt that a designated course in management pedagogy was either very or extremely important.

\section{Discussion}

The teachers in this study overwhelmingly reported they had found their university course in classroom management helpful. Approximately half of our sample had training that emphasized individualized behavioral interventions; while the other half had training that emphasized a classwide interactionalist approach to student behavior. However, participants in this study felt they had learned the most about management not from their coursework, but from their experiences in the field. Most of these teachers reported learning most through teaching in their own classrooms, while the remainder ranked their preservice fieldwork experiences as being most helpful. Whitney and colleagues (2002) reported similar results about the positive effects that student teaching and fieldwork experiences had on teachers' instructional and classroom management strategies. It has been long reported that field experiences allow preservice teachers opportunities to rehearse instructional decisions and reflective acts (Fuller, 1969; McBee, 1998; Stough, 2006). Many special education teacher training programs currently include field experiences that are tied to pedagogical coursework (Brownell et al., 2005), however little research exists on how these 
experiences affect the practice of experienced teachers (Stough \& Montague, 2015). Nevertheless, researchers have suggested that students who complete traditional teacher preparation programs are typically more skilled in classroom management than are their nontraditional peers (Brophy, 2006; Darling-Hammond, 2000).

Despite the relatively extensive training they had received, teachers in this study overwhelmingly expressed their desire for more training in classroom management, not only as part of their university preparation, but as part of their ongoing professional development. These findings are consistent with a number of other studies that have found that training in classroom management and the diverse needs of students are ongoing concerns for teachers, even for those who have graduated from highly-ranked university teacher preparation programs (e.g., Baker, 2005; Cardona Moltó, Florian, Rouse, \& Stough, 2010; Coalition for Psychology in Schools and Education, 2006; Nahal, 2010; Whitney, Golez, Nagel, \& Nieto, 2002). Similarly, training in classroom management has been repeatedly identified by professional teaching associations as both a continual and critical professional development need (see Oliver \& Reschly, 2007).

The experienced teachers in this study were asked about specific types of classroom management professional development that they needed. Most (40\%) identified general classroom management techniques. Similarly, educators in the MacPherson-Court et al (2003) study reported classroom management topics as a high priority, including proactive classroom management (97\%), theories of classroom management (90\%), and managing transitions (75\%). However, in our study, an additional one-third of the respondents identified disability-specific techniques as their most desired type of training. This finding is probably particular to samples of special education teachers such as ours, but noteworthy in that teachers may believe specialized forms of classroom management exist for teaching students with particular types of disability.

However, the need for classroom management, according to these educators, crossed special education and general education boundaries. One-hundred percent of the sample believed that both special educators and general educators would benefit from training in classroom management or behavioral interventions. Our findings are similar to those in the MacPhersonCourt et al (2003) survey in which over 95\% of preservice and experienced teachers responded that all preservice teachers - including special education majors and general education majors should receive training in classroom management and behavior management. Given the increasing inclusion of students with special needs in general education classrooms and the wide implementation of behavioral supports via a tiered system of supports and interventions, it does seem essential that both types of training, classroom management and behavioral interventions, be taught to all teachers, regardless of specialization. Brownell, Sindelar, Kiely, and Danielson (2010) point out that response to intervention (RTI) systems require that special education teachers need to have extensive knowledge related to interventionalist approaches (Tier 3) in order to be effective educators of students with disabilities. Our findings further their call for more extensive preservice preparation of special educators by suggesting that special educators need additional training in interactionalist whole-classroom management strategies as well.

\section{Limitations}

While participants in this study rated their coursework as having prepared them well in the area of classroom management, no statistical significance was found between the classroom management approach taught (either individual interventionist or whole-class interactionalist) in the course teachers had taken and the assessment of the effectiveness of the course. Our analysis was limited,

Journal of the Scholarship of Teaching and Learning, Vol. 15, No. 5, October, 2015. 
however, by the overall high ratings that these teachers gave to their coursework, regardless of theoretical approach or composition. Further studies with a larger sample would allow for a more powerful analysis on the effectiveness of different classroom management training approaches. Another limitation was that the instructional style of the instructors of these courses may have influenced participant responses, rather than the approach itself. Also, while this sample consisted of experienced special educators, some had left the field or changed teaching assignments after several years in the special education field. A more heterogeneous sample consisting of current special educational teachers would have been preferred but, as has been reported in the literature (Boe, Cook, \& Sunderland, 2008), special education teachers change positions frequently in the first decade of their careers. Despite these limitations, our results do suggest that preparation in classroom management is seen as essential by teachers and continues to be valued by them long after their university training has been completed.

\section{Implications}

The findings of this study point to the continued and persistent need for classroom management training. This training need extends beyond preservice and novice teachers-even experienced teachers reported a need for continued classroom management training. Further, the findings of this study highlight the importance of classroom management training, regardless of particular teaching specialty. Because of this reported need, school administrators are encouraged to seek out professional development opportunities to support the advancement of classroom management proficiency. Similarly, preservice programs should include opportunities for practice with classroom management skills throughout their training. While our findings support and extend existing literature on the need for classroom management training, further research is warranted on whether similar training needs exist within differently trained teachers (e.g., general education teachers, physical education teachers) or among teachers from other types of preservice training programs.

\section{Acknowledgements}

This research was supported in part by grants from the Texas A\&M University System Institute for School-University Partnerships and the Texas A\&M University Regents Initiative for Excellence in Education.

\section{References}

Anderson, L., Evertson, C., \& Brophy, J. (1979). An experimental study of effective teaching in first-grade reading groups. Elementary School Journal, 79, 193-223. http://dx.doi.org/10.1086/461151

Baker, P. H. (2005). Managing student behavior: How ready are teachers to meet the challenge? American Secondary Education, 33(3), 51-64. http://www.jstor.org/stable/41064554?seq=2\#page_scan_tab_contents

Berry, B., Hoke, M, \& Hirsch, E. (2004). The search for highly qualified teachers. Phi Delta Kappan, 85, 684-689. http://dx.doi.org/10.1177/003172170408500909 
Stough, Montague, Landmark, and Williams-Diehm

Boe, E. E., Cook, L. H., \& Sunderland, R. J. (2008). Teacher turnover: Examining exit attrition, teaching area transfer, and school migration. Exceptional Children, 73(1), 7-31.

http://ecx.sagepub.com/content/75/1/7.full.pdf

Brophy, J. (2006). History of research on classroom management. In C. M. Evertson \& C. S. Weinstein (Eds.), Handbook of classroom management: Research, practice, and contemporary issues (pp. 17-43). Mahwah, NJ: Lawrence Erlbaum Associates. doi:

10.4324/9780203874783.ch2

Brownell, M. T., Ross, D. D., Colón, E. P., \& McCallum, C. L. (2005). Critical features of special education teacher preparation: A comparison with general teacher education. The Journal of Special Education, 38, 242-252. doi:10.1177/00224669050380040601

Brownell, M. T., Sindelar, P. T., Kiely, M. T., \& Danielson, L. C. (2010). Special education teacher quality and preparation: Exposing foundations, constructing a new model. Exceptional Children, 76,(3), 357-377. doi: 10.1177/001440291007600307

Cardona Moltó, M. C., Florian, L., Rouse, M., \& Stough, L. M. (2010). Attitudes to diversity: a cross-cultural study of education students in Spain, England and the United States. European Journal of Teacher Education, 33(3), 245-264. doi:10.1080/02619768.2010.495771

Coalition for Psychology in Schools and Education. (2006, August). Report on the Teacher Needs Survey. Washington, D.C.: American Psychological Association, Center for Psychology in Schools and Education.

Darling-Hammond, L. (2000). How teacher education matters. Journal of Teacher Education, 51, 166-173. doi:10.1177/0022487100051003002

Emmer, E. T., \& Stough, L. M. (2001). Classroom management: A critical part of educational psychology and teacher education. Educational Psychologist, 36(2), 103-112. doi:10.1207/S15326985EP3602_5

Fuller, F. (1969). Concerns of teachers: A developmental conceptualization. American Educational Research Journal, 6, 207-226. doi:10.3102/00028312006002207

George, N. L., George, M. P., Gersten, R. \& Grosenick, J. K. (1995). To leave or to stay? An exploratory study of teachers of students with emotional and behavioral disorders. Remedial and Special Education, 16(4), 227-236. doi: 10.1177/074193259501600406

Gettinger, M., \& Kohler, K. M. (2006). Process-outcome approaches to classroom management and effective teaching. In C. M. Evertson \& C. S. Weinstein (Eds.), Handbook of classroom management: Research, practice, and contemporary issues (pp. 72-95). Mahwah, NJ: Lawrence Erlbaum Associates. doi: 10.4324/9780203874783.ch4

Journal of the Scholarship of Teaching and Learning, Vol. 15, No. 5, October, 2015. 
Stough, Montague, Landmark, and Williams-Diehm

Gilberts, G. H., \& Lignugaris-Kraft, B. (1997). Classroom management and instruction competencies for preparing elementary and special education teachers. Teaching and Teacher Education, 13(16), 597-610. http://dx.doi.org/10.1016/S0742-051X(97)80003-0

Glickman, C.D., \& Tamashiro, R.T. (1980). Clarifying teachers' beliefs about discipline. Educational Leadership, 37(6), 459-464 doi: 10.1177/019263658006444019

Jones, V. (2006). How do teachers learn to be effective classroom managers? In C. M. Evertson \& C. S. Weinstein (Eds.), Handbook of classroom management: Research, practice, and contemporary issues (pp. 887-907). Mahwah, NJ: Lawrence Erlbaum Associates. doi: 10.4324/9780203874783.ch33

Kaplan, L. S., Owings, W. A. (2003). No child left behind: The politics of teacher quality. Phi Delta Kappan, 84, 687-692. http://dx.doi.org/10.1177/003172170308400909

Kee, A. N. (2011). Feelings of preparedness among alternatively certified teachers: What is the role of program features? Journal of Teacher Education, 63(1), 23-38. http://dx.doi.org/10.1177/0022487111421933

MacPherson-Court, L., McDonald, L, \& Sobsey, D. (2003). Inclusive education survey: Meeting the educational needs of preservice teachers. Developmental Disabilities Bulletin, 31(1), 57-85.

Martin, N. K., Shoho, A. R., \& Yin, Z. (2003). Attitudes and beliefs regarding classroom management styles: The impact of teacher preparation versus experience. Research in the Schools, 10(2), 29-34.

McBee, R. (1998). Readying teachers for real classrooms. Educational Leadership, 55(5), 56-58.

Meister, D. G. \& Melnick, S. A. (2003). National new teacher study: Beginning teachers' concerns. Action in Teacher Education, 24(4), 87-94. doi:10.1080/01626620.2003.10463283

Mitchell, A. \& Arnold, M. (2004). Behavior management skills as predictors of retention among south Texas special educators. Journal of Instructional Psychology, 31(3), 214-219. http://web.a.ebscohost.com/ehost/pdfviewer/pdfviewer?sid=038d4014-4d6c-45c5-a656-

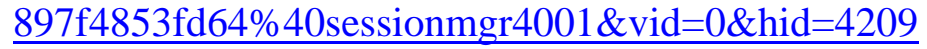

Nahal, S. P. (2010). Voices from the field: Perspectives of first-year teachers on the disconnect between teacher preparation programs and the realities of the classroom. Research in Higher Education, 8, 1-19. http://m.aabri.com/manuscripts/10446.pdf

O’Neill, S., \& Stephenson, J. (2012). Does classroom management coursework influence preservice teachers' perceived preparedness or confidence? Teaching and Teacher Education, 28, 1131-1143. http://dx.doi.org/10.1016/j.tate.2012.06.008

Journal of the Scholarship of Teaching and Learning, Vol. 15, No. 5, October, 2015. Josotl.Indiana.edu 
Stough, Montague, Landmark, and Williams-Diehm

Oliver, R. M., \& Reschly, D. J. (2007). Effective classroom management: Teacher preparation and professional development. Washington, DC: National Comprehensive Center for Teacher Quality. Retrieved from http://www.tqsource.org/topics/effectiveClassroomManagement.pdf

Oliver, R.M., \& Reschly, D.J. (2010). Special education teacher preparation in classroom management: Implications for students with emotional and behavioral disorders. Behavioral Disorders, 35(3), 188-199. doi: 10.4324/9780203817032.ch17

Omoteso, B. \& Semudara, A. (2011). The relationship between teachers' effectiveness and management of classroom misbehaviours in secondary schools. Psychology, 2, 902-908. doi: 10.4236/psych.2011.29136

Schonfeld, I. S., \& Feinman, S. J. (2012). Difficulties of alternatively certified teachers. Education and Urban Society, 44(3), 215-246. doi: 10.1177/0013124510392570

Stough, L. M. (2006). The place of classroom management and standards in teacher education. In C. Evertson \& C. Weinstein, (Eds.). Handbook of classroom management: Research, practice, and contemporary issues (pp. 909-923). Mahwah, NJ: Erlbaum. 10.4324/9780203874783.ch34

Stough, L. M., \& Montague, M. L. (2015). How teachers learn to be classroom managers. In E. Emmer (Ed), Handbook of classroom management: Research, practice, and contemporary issues. Mahwah, NJ: Erlbaum.

Stough, L. M., \& Palmer, D. J. (2001, April). Teacher reflection: How effective special educators differ from novices. Paper presented at the annual meeting of the Council for Exceptional Children, Kansas City, MO. (ERIC Document No. ED463279).

Stough, L. M., Williams, K., \& Montague, M. (2004, November). Classroom management content in teacher preparation programs. Paper presented at the Teacher Education Division of the Council for Exceptional Children, Albuquerque, NM.

Stronge, J. H., Ward, T. J., \& Grant, L. W. (2011). What makes good teachers good? A crosscase analysis of the connection between teacher effectiveness and student achievement. Journal of Teacher Education. 62, 339-355. doi:10.1177/0022487111404241

Veenman, S. (1984). Perceived problems of beginning teachers. Review of Educational Research, 54, 143-178. doi:10.3102/00346543054002143

Wang, M. C., Haertel, G. D., \& Walberg, H. G. (1993). Toward a knowledge base for school learning. Review of Educational Research, 63(3), 249-294. doi: 10.3102/00346543063003249

Watson, S. B. (2006). Novice science teachers: Expectations and experiences. Journal of Science Teacher Education, 17, 279-290. doi:10.1007/s10972-006-9010-y

Journal of the Scholarship of Teaching and Learning, Vol. 15, No. 5, October, 2015. Josotl.Indiana.edu 
Stough, Montague, Landmark, and Williams-Diehm

Whitaker, S. D. (2003). Needs of beginning special education teachers: Implications for teacher education. Teacher Education and Special Education, 26(2), 106-117. doi:

$10.1177 / 088840640302600204$

White, M. \& Mason, C. Y. (2006). Components of a successful mentoring program for beginning special education teachers: Perspectives from new teachers and mentors. Teacher Education and Special Education, 29(3), 191-201. doi: 10.1177/088840640602900305

Whitney, L., Golez, F., Nagel, G., \& Nieto, C. (2002). Listening to voices of practicing teachers to examine the effectiveness of a teacher education program. Action in Teacher Education, 23(4), 69-76. doi:10.1080/01626620.2002.10463090

Journal of the Scholarship of Teaching and Learning, Vol. 15, No. 5, October, 2015. 